\title{
Front Matter: Volume 9180
}

, "Front Matter: Volume 9180," Proc. SPIE 9180, Laser Processing and Fabrication for Solar, Displays, and Optoelectronic Devices III, 918001 (10 November 2014); doi: 10.1117/12.2176695

SPIE Event: SPIE Solar Energy + Technology, 2014, San Diego, California, United SPIE. States 


\title{
PROCEEDINGS OF SPIE
}

\section{Laser Processing and Fabrication for Solar, Displays, and Optoelectronic Devices III}

\author{
Edward W. Reutzel \\ Editor
}

20-21 August 2014

San Diego, California, United States

Sponsored and Published by

SPIE 
The papers included in this volume were part of the technical conference cited on the cover and title page. Papers were selected and subject to review by the editors and conference program committee. Some conference presentations may not be available for publication. The papers published in these proceedings reflect the work and thoughts of the authors and are published herein as submitted. The publisher is not responsible for the validity of the information or for any outcomes resulting from reliance thereon.

Please use the following format to cite material from this book:

Author(s), "Title of Paper," in Laser Processing and Fabrication for Solar, Displays, and Optoelectronic Devices III, edited by Edward W. Reutzel, Proceedings of SPIE Vol.9180 (SPIE, Bellingham, WA, 2014) Article CID Number.

ISSN: 0277-786X

ISBN: 9781628412079

Published by

SPIE

P.O. Box 10, Bellingham, Washington 98227-0010 USA

Telephone +1 3606763290 (Pacific Time) · Fax +1 3606471445

SPIE.org

Copyright (@ 2014, Society of Photo-Optical Instrumentation Engineers.

Copying of material in this book for internal or personal use, or for the internal or personal use of specific clients, beyond the fair use provisions granted by the U.S. Copyright Law is authorized by SPIE subject to payment of copying fees. The Transactional Reporting Service base fee for this volume is $\$ 18.00$ per article (or portion thereof), which should be paid directly to the Copyright Clearance Center (CCC), 222 Rosewood Drive, Danvers, MA 01923. Payment may also be made electronically through CCC Online at copyright.com. Other copying for republication, resale, advertising or promotion, or any form of systematic or multiple reproduction of any material in this book is prohibited except with permission in writing from the publisher. The CCC fee code is 0277-786X/14/\$18.00.

Printed in the United States of America.

Publication of record for individual papers is online in the SPIE Digital Library.

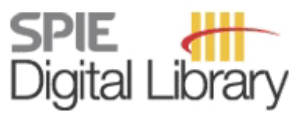

SPIEDigitalLibrary.org

Paper Numbering: Proceedings of SPIE follow an e-First publication model, with papers published first online and then in print and on CD-ROM. Papers are published as they are submitted and meet publication criteria. A unique, consistent, permanent citation identifier (CID) number is assigned to each article at the time of the first publication. Utilization of CIDs allows articles to be fully citable as soon as they are published online, and connects the same identifier to all online, print, and electronic versions of the publication. SPIE uses a six-digit CID article numbering system in which:

- The first four digits correspond to the SPIE volume number.

- The last two digits indicate publication order within the volume using a Base 36 numbering

system employing both numerals and letters. These two-number sets start with 00, 01, 02, 03, 04, 05, 06, 07, 08, 09, 0A, 0B ... 0Z, followed by 10-1Z, 20-2Z, etc.

The CID Number appears on each page of the manuscript. The complete citation is used on the first page, and an abbreviated version on subsequent pages. Numbers in the index correspond to the last two digits of the six-digit CID Number. 


\title{
Contents
}

\author{
$\checkmark \quad$ Authors \\ vii Conference Committee \\ ix The renaissance of CdTe-based photovoltaics (Solar Energy Plenary Paper) [9177-302] \\ xvii Hot carrier solar cell absorbers: materials, mechanisms and nanostructures \\ (Solar Energy Plenary Paper) [9178-304] \\ xxix International PV QA Task Force's proposed comparative rating system for $P V$ modules \\ (Solar Energy Plenary Paper) [9179-305]
}

\section{SESSION 1 LASER PROCESSING FOR SOLAR, DISPLAYS, AND OPTOELECTRONICS}

918002 Overview of laser processing in solar cell fabrication (Invited Paper) [9180-1]

918004 Laser processing of glass for consumer electronics: opportunities and challenges (Invited Paper) [9180-3]

918005 Laser microprocessing technologies for automotive, flexible electronics, and solar energy sectors (Invited Paper) [9180-4]

\section{SESSION 2 LASER TEXTURING}

918006 New strategies in laser processing of TCOs for light management improvement in thin-film silicon solar cells (Invited Paper) [9180-8]

918007 Influence of surface modification by laser beam interference ablation on characteristics of p-Si solar cells [9180-5]

918008 Laser doping of germanium for photodetector applications [9180-6]

918009 Formation of periodic structures on silicon by laser beam interference ablation technique for light control in solar cells [9180-7]

$91800 \mathrm{~A}$ Near-field assisted nanoscale patterning for improved absorption in thin film silicon solar cell [9180-22]

\section{SESSION $3 \quad$ MODELING AND INNOVATIVE TECHNIQUES}

9180 OD Laser processing and in-situ diagnostics for crystallization: from thin films to nanostructures (Invited Paper) [9180-11] 
9180 OF Sub-bandgap laser annealing of room temperature deposited polycrystalline CdTe [9180-13]

$9180 \mathrm{OH}$ Silicon PV module customization using laser technology for new BIPV applications [9180-15]

\section{SESSION 4 PATTERNING AND SCRIBING}

9180 ol Selective laser patterning in organic solar cells (Invited Paper) [9180-16]

$9180 \mathrm{OK}$ The effect of film properties and laser processing parameters on the laser ablation of molybdenum thin films [9180-18]

9180 OM Patterning of OPV modules by ultra-fast laser [9180-20] 


\section{Authors}

Numbers in the index correspond to the last two digits of the six-digit citation identifier (CID) article numbering system used in Proceedings of SPIE. The first four digits reflect the volume number. Base 36 numbering is employed for the last two digits and indicates the order of articles within the volume. Numbers start with 00, 01, 02, 03, 04, 05, 06, 07, 08, 09, OA, OB...0Z, followed by 10-1Z, 20-2Z, etc.

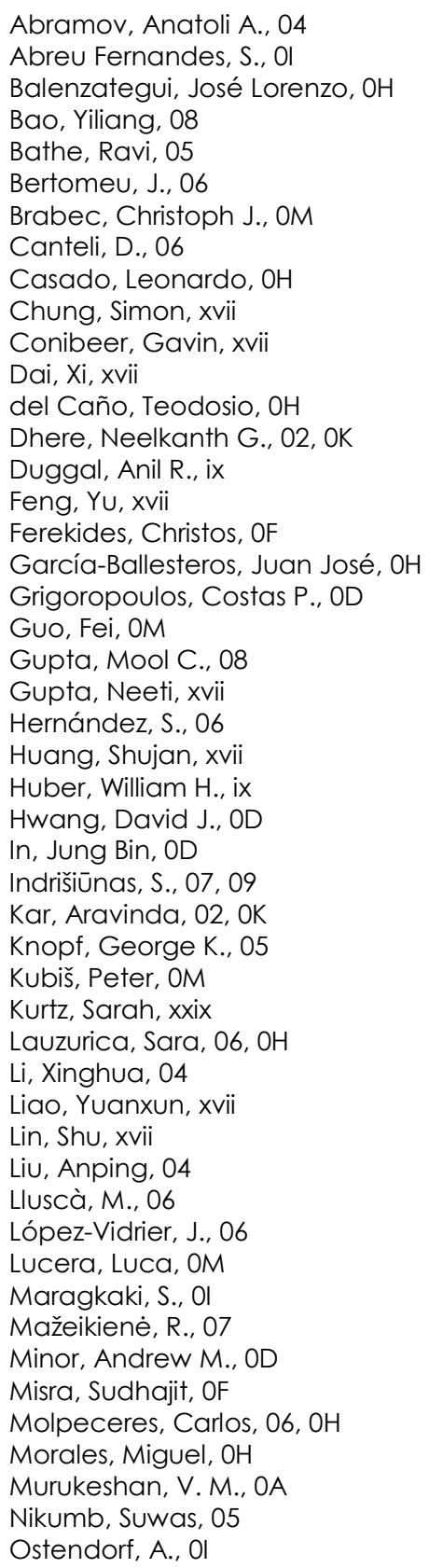

\author{
Patterson, Robert, xvii \\ Paudel, Naba, OF \\ Prabhathan, P., OA \\ Račiukaitis, G., 07, 09 \\ Rèza, A., 07 \\ Rodrigues, Rafael, OK \\ Ryu, Sang-Gil, OD \\ Salleo, Alberto, OF \\ Sánchez-Aniorte, M. I., 06 \\ Scarpulla, Michael A., OF \\ Schneller, Eric, 02, OK \\ Selskis, A., 07 \\ Shrestha, Santosh, xvii \\ Sidharthan, R., OA \\ Šimkienè, I., 07, 09 \\ Simonds, Brian J., OF \\ Smyth, Suntrana, xvii \\ Spyropolous, George, OM \\ Streltsov, Alexander M., 04 \\ Sun, Keye, 08 \\ Suzanovičienè, R., 09 \\ Tayebjee, Murad, xvii \\ Valencia, Daniel, $\mathrm{OH}$ \\ Vandewal, Koen, OF \\ Voigt, Monika M., OM \\ Voisiat, B., 07, 09 \\ Wang, Pei, xvii \\ Wohlgemuth, John, xxix \\ Xia, Hongze, xvii \\ Xiang, Bin, OD \\ Yoo, Jae-Hyuck, OD \\ Zhang, Pengfei, xvii \\ Zhang, Zhilong, xvii \\ Zheng, Andy Cheng, OD
}


Proc. of SPIE Vol. $9180918001-6$

Downloaded From: https://www.spiedigitallibrary.org/conference-proceedings-of-spie on 26 Apr 2023 Terms of Use: https://www.spiedigitallibrary.org/terms-of-use 


\title{
Conference Committee
}

\author{
Symposium Chair
}

Oleg V. Sulima, GE Global Research (United States)

Conference Chair

Edward W. Reutzel, Applied Research Laboratory, The Pennsylvania State University (United States)

Conference Co-Chairs

Aravinda Kar, CREOL, The College of Optics and Photonics, University of Central Florida (United States)

David Jae-Seok Hwang, Stony Brook University (United States)

Carlos Molpeceres, Universidad Politécnica de Madrid (Spain)

Conference Program Committee

Christoph J. Brabec, Friedrich-Alexander-Universität ErlangenNürnberg (Germany)

Douglas B. Chrisey, Tulane University (United States)

Corey M. Dunsky, AEOS Consulting (United States)

Mool Chandra Gupta, University of Virginia (United States)

Anthony P. Hoult, IPG Photonics Corporation (United States)

Samuel S. Mao, Lawrence Berkeley National Laboratory

(United States) and University of California, Berkeley (United States)

Jan Nekarda, Fraunhofer-Institut für Solare Energiesysteme (Germany)

Michael A. Scarpulla, The University of Utah (United States)

Session Chairs

1 Laser Processing for Solar, Displays, and Optoelectronics

Edward W. Reutzel, Applied Research Laboratory, The Pennsylvania State University (United States)

2 Laser Texturing

Carlos Molpeceres, Universidad Politécnica de Madrid (Spain)

3 Modeling and Innovative Techniques

Aravinda Kar, CREOL, The College of Optics and Photonics, University of Central Florida (United States)

$4 \quad$ Patterning and Scribing

Edward W. Reutzel, Applied Research Laboratory, The Pennsylvania State University (United States) 
Proc. of SPIE Vol. $9180918001-8$

Downloaded From: https://www.spiedigitallibrary.org/conference-proceedings-of-spie on 26 Apr 2023 Terms of Use: https://www.spiedigitallibrary.org/terms-of-use 